\title{
PEMANFAATAN AIR SUNGAI BAWAH TANAH GUA SURUH UNTUK MASYARAKAT DESA PUCUNG, EROMOKO, WONOGIRI
}

\author{
Agus Anggoro Sigit, Kuswaji Dwi Priyono, \\ dan Yuli Priyana \\ Fakultas Geografi \\ Universitas Muhammadiyah Surakarta \\ Email: Kuswaji.Priyono@ums.ac.id
}

\begin{abstract}
The village has a population Eromoko Pucung in District 444 families (2,354 people) which includes 7 hamlet, in the dry season is always a shortage of clean water for daily use. At the peak of the dry season are forced to buy water being sold privately at a price of Rp200,000/ car tank (volume $4 \mathrm{~m}^{3}$ ) for the use of approximately 20 days. In order to overcome the problems of water needs, the Pucung Village Government took the initiative to manage groundwater resources that exist in the Suruh Cave. Removal activities river water underground community empowerment aimed at utilization of underground water in the Cave Have to solving the problem of water supply daily needs of society in Pucung Village, District Eromoko, Wonogiri. The success of water removal program is expected to reduce the price of $1 \mathrm{~m}^{3}$ water needs of the original with a maximum price of $R p$ 50,000 to $R p$ 5,000 only.
\end{abstract}

Kata kunci: pengelolaan air, sungai bawah tanah, Gua Suruh.

\section{PENDAHULUAN}

Wilayah Kabupaten Wonogiri terkenal dengan daerah yang gersang, setiap tahun terjadi bencana kekeringan, lahan pertaniannya berbatu, dikenal sebagai Perbukitan Seribu (istilah Jawa "Gunung Sewu"). Kabupaten Wonogiri terletak memiliki wilayah seluas 182.263,02 ha atau sekitar 5,59\% luas wilayah Provinsi Jawa Tengah terletak antara $110^{\circ} 41^{\prime}-111^{\circ} 18^{\prime}$ BT dan $7^{\circ} 32^{\prime}-8^{\circ} 15^{\prime}$ LS. Batas wilayahnya di sebelah utara dengan Kabupaten Karanganyar dan Sukoharjo, sebelah timur berbatasan dengan Kabupaten Magetan dan Ponorogo Provinsi Jawa Timur, sebelah selatan berbatasan dengan Kabupaten Pacitan dan Samudera Indonesia, dan sebelah barat berbatasan dengan Provinsi Daerah Istimewa
Yogyakarta. Secara adiministrasi terbagi 25 Kecamatan, 251 Desa, 43 Kelurahan, dan 2.306 Dusun/lingkungan. Jumlah Kepala Keluarga (KK) mencapai 375.701 KK dengan rata-rata jumlah jiwa dalam 1 (satu) KK sebanyak 3-5 jiwa/KK, kepadatan penduduk per kecamatan antara 369 - 1.481 jiwa/km² (Bappeda Kabupaten Wonogiri, 2011).

Wilayah Kabupaten Wonogiri khususnya di bagian selatan merupakan daerah rawan bencana kekeringan, ada 7 kecamatan yang termasuk dalam kategori rawan kekeringan yaitu: Pracimantoro, Paranggupito, Giritontro, Giriwoyo, Batuwarno, Manyaran, dan Eromoko yang menyebar di 41 desa/ kelurahan dengan 75.000 jiwa atau 17.260 KK (kepala keluarga). Desa Pucung di 
Kecamatan Eromoko dengan jumlah $444 \mathrm{KK}$ (2.354 jiwa) yang meliputi 7 dusun, pada musim kemarau selalu kekurangan air bersih untuk keperluan sehari-hari. Usaha masyarakat untuk mencukupi kebutuhan air minum masih sederhana dengan membuat bak penampung air hujan dan membuat cekungan/lubangan di sekitar telaga saat menjelang musim kemarau. Pada puncak musim kemarau terpaksa membeli air bersih yang dijual pihak swasta dengan harga mencapai Rp200.000/mobil tangki (volume $4 \mathrm{~m}^{3}$ ) untuk pemakaian sekitar 20 hari. Masyarakat Desa Pucung mayoritas bekerja sebagai petani dan buruh dengan penghasilan di bawah rata-rata, sedangkan kebutuhan air semakin meningkat. Penduduk yang kurang mampu membeli air dari swasta, terpaksa menunggu bantuan dari Dinas Sosial atau organisasi masyarakat berupa bantuan droping air yang dibatasi jatahnya (lihat gambar 1dan 2 berikut).

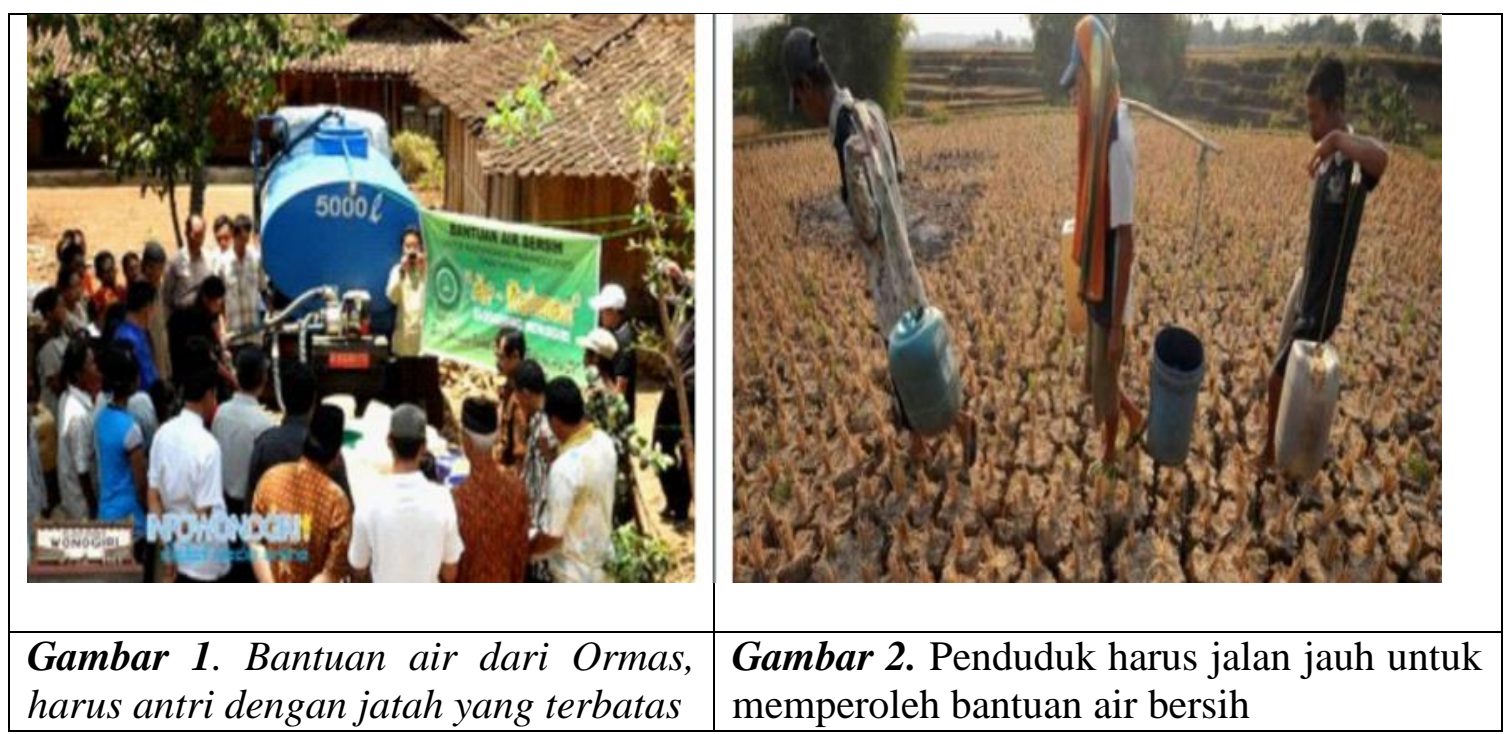

Guna mengatasi permasalahan kebutuhan air, Pemerintah Desa Pucung berinisiatif untuk mengelola sumber air bawah tanah yang ada di dalam Gua Suruh. Secara fisik mulut gua (entrance) terletak pada pusat depresi atau cekungan. Berdasarkan hasil penelusuran gua oleh KMPA Giri Bahama Fakultas Geografi UMS, Gua Suruh ini memiliki lorong vertical atau sumuran $17 \mathrm{~m}$ dan $11,5 \mathrm{~m}$ dengan panjang lorong sekitar $1.500 \mathrm{~m}$ yang di dalamnya terdapat sungai bawah tanah dengan debit rata-rata 2 lt/dt mendekati konstan sepanjang tahun (lihat Gambar 3 berikut). Pemerintah Desa Pucung telah menjalin kerjasama dan melakukan koordinasi dengan mahasiswa KMPA Giri Bahama Fakultas Geografi UMS di bawah bimbingan Dosen Pembimbing untuk melakukan eksploitasi air bawah tanah di Gua Suruh telah meguna mengatasi bencana kekeringan yang setiap tahun (JuliSeptember) terjadi di Desa Pucung. 


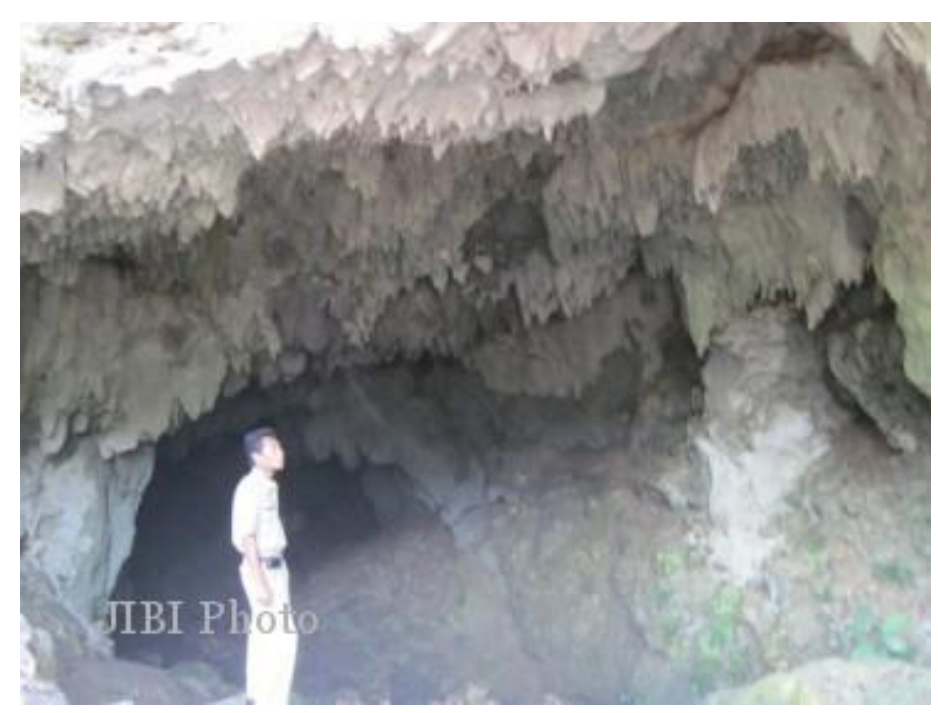

\section{Gambar 3. Kepala Desa Pucung di depan mulut Gua Suruh, bertekat untuk mengatasi masalah kebutuhan air masyarakatnya}

Kondisi hidrologi daerah ini adalah tidak dijumpainya air permukaan karena sebagian besar air yang jatuh ke permukaan langsung masuk kedalam tanah karena batuannya porus, sehingga hampir sebagian besar tersimpan dalam sungai bawah tanah. Penduduk di daerah ini menggunakan air penampung air hujan untuk memenuhi kebutuhan hidup sehari-hari. Jenis flora yang terdapat daerah ini adalah ketela, jati, kelapa, jagung, kacang tanah dan padi gogo. Jenis tanaman ini ditanam pada bagian yang tanahnya sudah berkembang atau pada cekungan-cekungan yang biasanya terisi oleh tanah terrarosa/mediteran. Penggunaan lahan di daerah ini didominasi oleh pertanian lahan kering yaitu sebagai tegalan dan sawah tadah hujan dengan ditanami ketela, jagung dan padi. Penggunaan lahan seperti ini biasanya terbatas pada cekungan-cekungan seperti polye dimana pada cekungan tersebut terdapat material hasil pelapukan batugamping yang berkembang menjadi tanah terrarosa sehingga lahan dapat diusahakan. Penduduk setempat sudah berusaha menyesuaikan dengan kondisi alam yang kurang mendukung dengan berbagai percobaan tanaman yaitu mencari tanaman yang cocok untuk bentuklahan seperti ini (Adji, TN., 2006).

Daerah ini termasuk dalam kategori pedesaan yang usaha utamanya adalah pertanian lahan kering. Penduduknya didominasi oleh penduduk usia tua dan anakanak karena banyaknya migrasi keluar dari daerah ini. Karena pertumbuhan penduduk yang lambat maka umlah penduduknya menjadi sedikit. Hal ini disebabkan oleh tingginya angka migrasi keluar dan kondisi lingkungan alam yang tidak mendukung untuk perkembangan penduduk. Pola permukiman didaerah ini berpola menggerombol tetapi menyebar dengan bentuk yang sederhana dan kualitas yang belum cukup baik (Adji, TN., 2006).. Kegiatan ekonomi di wilayah ekosistem bentanglahan karst harus ekstra hati-hati mengingat sifat batuan yang sangatorus dan memiliki permeabilitasekunder yang mampu meneruskan aliran air limbah ke segala arah mengikuti retakan diaklas. Tingkat ekonomi di daerah ini tergolong masih rendah karena banyaknya penduduk yang keluar daerah untuk mencari pekerjaan yang baru. Rata-rata penduduk disini bermata pencaharian sebagai peladang atau petani lahan kering. Adapun tanaman yag 
diusahakan adalah berupa jati, ketela, dan padi gogo. Kondisi pendidikan dan kesehatannya relatif masih rendah terlihat dari masih sedikitnya fasilitas pendidikan dan kesehatan yang ada didaerah ini. Adatistiadat atau tradisi masih dipertahankan seperti kepercayaan terhadap mitos-mitos, namun daripada itu karena kondisi alam yang tidak mendukung kehidupan, banyak penduduk yang bunuh diri karena keputusasaan mereka dalam menghadapi kondisi alam yang sangat keras.

Bahaya lingkungan karst (karstic environmental hazard) yang ditandai oleh adanya bencana kekeringan secara periodik (5 - 9 bulan) yang berakibat pada kesulitan air untuk tanaman, hewan dan manusia. Kekurangan pangan dan gizi bisa terjadi dan mengganggu kesehatan manusia terutama di musim kemarau panjang. Produktivitas lahan pertanian sangat terbatas dan pendapatan masyarakat rendah sehingga dijumpai beberapa keluarga prasejahtera (miskin). Namun daripada itu banyak permasalahan yang muncul di daerah ini seperti keterbatasan SDA untuk pengembangan permukiman dan pertanian, krisis air bersih, banyaknya migrasi keluar khususnya penduduk usia produktif sehingga pengembangan ekonomi sangat lambat, dan juga banyaknya kasus bunuh diri karena tekanan ekonomi.Bahaya lingkungan sosial terjadi oleh pengaruh bahaya lingkungan fisikal. Apabila penduduk di lingkungan karst mengalami kesulitan air, pangan, dan penghasilan maka ada kemungkinan mengalami stres dan rentan terhadap penyakit dan kematian.

Mitra I : Profil masyarakat yang akan diberdayakan dalam kegiatan pengangkatan dan distribusi air bawah tanah di Gua Suruh, Desa Pucung adalah seluruh warga yang tinggal di Desa Pucung yang meliputi 444 KK (2.354 jiwa). Sebagian besar warga adalah petani dan buruh dengan penghasilan di bawah rata-rata upah minimal regional (UMR) mengharap sekali masalah kebutuhan air segera dapat diatasi. Setiap musim kemarau, ketika bak air dan telaga sudah kering mengandalkan bantuan droping air yang terbatas untuk minum saja sementara mereka harus menahan tidak mandi dengan layak. Mereka membutuhkan pendamping terkait cara pengelolaan air bawah tanah di dalam Gua Suruh yang sangat besar debitnya namun belum dapat dimanfaatkan. Kegotongroyongan sebagai masyarakat pedesaan masih sangat besar dari Penduduk Desa Pucung, secara bergantian penduduk sanggup memberi akomodasi makan seharihari untuk Tim Relawan KMPA Giri Bahama. Kebutuhan yang mereka harapkan adalah bantuan pompa untuk mengangkat air dalam gua dan teknis pemompaannya, kelanjutan dari pemeliharaan pelestarian gua dan distribusinya secara gotongroyong akan terus dilakukan.

Mitra II : Pihak KMPA Giri Bahama Fakultas Geografi adalah mahasiswa yang sejak Tahun 2000 telah melakukan berbagai kegiatan terkait kepecintaan alam di Desa Pucung. Mereka sudah menjadi warga kehormatan yang meramaikan aktivitas warga Desa, adapun kegiatan yang telah dilakukan meliputi: (1) koleksi data mulut gua dan telaga tahun 2000, (2) penelitian untuk mengetahui keberadaan dan persebaran gua di Desa Pucung, (3) penelitian pendugaan sistem sungai bawah tanah melalui survey speologi tahun 2001, (4) penelitian terkait sistem penyediaan dan pola konsumsi air di Desa Pucung, (5) penelitian tentang potensi kawasan karst untuk obyek pariwisata minat khusus di Desa Pucung, dan (6) kegiatan penyuluhan tentang pengelolaan karst, pelatihan penelusuran gua yang aman, dan koleksi pengukuran data debit air sungai bawah tanah tahun 20062010 yang didapatkan debit rata-rata sebesar 2 lt/dt. Pengalaman dalam kegiatan penelurusan gua juga telah dilakukan di wilayah lain di Wonogiri, mereka berkeyakinan besar dapat membantu mengatasi permasalahan penyediaan air 
bersih untuk kebutuhan sehari-hari di Desa Pucung sebagai relawan penelusuran gua dengan mengangkat air bawah tanah yang ada.

Keberhasilan program pengangkatan air sungai bawah tanah di Gua Suruh, Desa Pucung ini diharapkan dapat meningkatkan taraf hidup masyarakat. Beban masyarakat untuk membeli air dari tangki swasta dan antrian dengan jatah terbatas bagi warga yang tidak mampu dapat segera teratasi. Alokasi dana rutin tahunan saat musim kemarau untuk membeli air yang mahal dapat dialihkan melalui pengembangan ekonomi sektor pertanian dan peternakan sehingga dapat meningkatkan kesejahteraan masyarakat Desa Pucung.

\section{METODE KEGIATAN}

Kegiatan pengangkatan air sungai bawah tanah berbasis pemberdayaan masyarakat diarahkan pada pemanfaatan air bawah tanah di Gua Suruh untuk pemecahan masalah penyediaan air kebutuhan seharihari masyarakat di Desa Pucung, Kecamatan Eromoko, Kabupaten Wonogiri. Tahapan kegiatan kegiatan yang harus dilakukan meliputi:

1 Peninjauan kembali peta gua atau luweng dan pengukuran ulang debit air sungai bawah tanah.

2 Penyiapan jalur vertical untuk keselamatan dan transport material, serta pelatihan penggunaan alat pekerjaan vertical kepada masyarakat.

3 Persiapan pembuatan bendungan, pekerjaan bendungan, dan perencanaan jalur pipa dan kabel.

4 Pengangkatan air sungai bawah tanah dan pembuatan bak penyalur kepada warga.

Dalam pelaksanaan kegiatan pengangkatan air sungai bawah tanah di Gua Suruh Desa Pucung ini, rincian masingmasing tahapan kegiatan sebagai berikut.

1. Tahap pertama, peninjauan kembali peta gua atau luweng yang telah dipetakan oleh Tim KMPA Giri Bahama, ceking peralatan pekerjaan vertikal dalam penelusuran gua, alat komunikasi, dan GPS penelusuran lorong-lorong gua yang telah menjadi andalan kegiatan Tim KMPA Giribahama selama ini.

2. Tahap kedua, menentukan jalur vertikal yang akan digunakan untuk penyaluran bahan bendungan di dalam Gua Suruh sekaligus pelatihan warga masyarakat yang dilibatkan dalam pengerjaan bendungan.

3. Tahap ketiga, persiapan pembuatan bendungan hasil pembicaraan tim Dosen pembimbing, tim KMPA Giribahama dan warga masyarakat yang ditunjuk secara bergilir dalam pengerjaan bendungan.

4. Tahap keempat, pengangkatan air dengan pemompaan menggunakan pompa Submersible dalam air disalurkan ke bak penyaluran air kepada warga.

Kegiatan pengabdian masyarakat di Desa Pucung ini bertujuan untuk pemenuhan kebutuhan air keperluan harian bagi warga Desa Pucung. Kerjasama seluruh masyarakat di Desa Pucung dalam pemanfaatan air sungai bawah tanah Gua Suruh menjadi kunci keberlanjutan program pengabdian ini. Keberhasilan program pengangkatan air sungai bawah tanah di Gua Suruh, Desa Pucung, Kecamatan Eromoko diharapkan dapat meningkatkan taraf hidup masyarakat.

\section{Luaran bagi masyarakat Desa Pucung}

Berhasilnya program pengangkatan air diharapkan dapat menekan harga kebutuhan air tiap $1 \mathrm{~m}^{3}$ dari semula dengan harga $\mathrm{Rp}$ 50.000 menjadi maksimal Rp 5.000 saja. Harga air tangki pada Tahun 2012 tiap tangki berkisar Rp 200.000 dengan volume $4 \mathrm{~m}^{3}$, sehingga tiap $1 \mathrm{~m}^{3}$ air seharga Rp 50.000. Kebutuhan air rata-rata di 7 Dusun yang memerlukan air (Dusun Pule, Brengkut, Gundi, Kangkung, Turi, Mijil, dan Jalakan) adalah 22,05 liter/orang/hari. Dengan terangkatnya air sungai bawah tanah di Gua Suruh ini dapat terpenuhi 27,52 liter/orang/ hari dengan asumsi dari debit pompa 1,5 liter 
dikalikan waktu pemompaan 12 jam (43.200 detik) dibagi jumlah penduduk (2.354 jiwa).

\section{Luaran bagi mahasiswa KMPA Giribahama}

Pengangkatan air sungai bawah tanah di Gua Suruh memberi pengalaman dalam pendampingan masyarakat yang selama ini mempunyai masalah kebutuhan air. Kegiatan penelusuran gua (caving) yang dilakukan memberi informasi keberadaan sumber air yang ada dalam gua yang dapat diangkat dengan pemompaan untuk dimanfaatkan oleh masyarakat Desa Pucung. Terjalinnya sinergitas KMPA Giribahama dengan masyarakat Desa Pucung selanjutnya dapat dijadikan untuk pelatihan mahasiswa dalam kegiatan penelusuran gua. Gua Suruh dapat digunakan sebagai lokasi pengkaderan mahasiswa yang bergiat dalam kegiatan pecinta alam yang bersinergi dengan pendampingan masyarakat.

\section{Luaran bagi warga yang dilibatkan}

Kegiatan pengangkatan sumber air bawah tanah di Gua Suruh, Desa Pucung ini diharapkan akan berdampak pada kegiatan masyarakat yang semakin beragam. Keindahan Gua Suruh dapat dimanfaatkan untuk Wisata Minat Khusus Caving (Penelusuran Gua) sehingga pengalaman pelatihan penelusuran gua kepada pemuda Desa Pucung dalam kegiatan pengangkatan air, selanjutnya dapat digunakan sebagai Profesi Pemandu Wisata Gua. Pemuda yang dilibatkan dalam kegiatan ini sebanyak 6 orang, kebanyakan pemuda desa urbanisasi ke kota bekerja sebagai buruh di Kota. Ketersediaan air bagi penduduk Desa Pucung yang berusia produktif sekitar 1.253 jiwa akan terlibat dalam kegiatan yang berkelanjutan dalam pemanfaatan air untuk budidaya peternakan lele atau belut serta pertanian sayuran yang dibutuhkan seharihari (cabai, terong, bayam, dan jagung). Kegiatan wisata minat khusus Penelusuran Gua di Desa Pucung selanjutnya akan berdampak pada kegiatan jasa penginapan, warung makan, dan ekonomi lainnya.

Kegiatan pengelolaan air bawah tanah Gua Suruh di Desa Pucung ini bermanfaat bagi warga, mahasiswa pecinta alam Giri Bahama, dan pemuda pemandu wisata gua. Bagi warga manfaatnya adalah penghematan dalam pemenuhan kebutuhan air bersih harian. Bagi mahasiswa pecinta alam Giri bahama kegiatan ini sebagai kegiatan pengkaderan anggota terkait dengan penelusuran gua, dan bagi pemuda desa menjadi kegiatan ekonomi kreatif terkait dengan pemandu wisata Gua. Secara sinergis kegiatan pengabdian masyarakat ini adalah dalam pemanfaatan sumberdaya alam kawasan karst sekaligus usaha pelestarian karst, sehingga ekosistem karst sebagai kawasan penyangga air kebutuhan penduduk sehari-hari dapat terjaga.

Kegiatan pemberdayaan masyarakat Desa Brengkut dalam pemanfaatan air sungai bawah tanah Gua Suruh yang dipusatkan di Dusun Brengkut ini adalah perwakilan warga dari 7 Dusun yang memerlukan air (Dusun Pule, Brengkut, Gundi, Kangkung, Turi, Mijil, dan Jalakan). Dalam pelaksanaan kegiatan penyaluran air ke 7 dusun tersebut dilakukan secara bergilir, sehingga tim pendamping menjadwal perwakilan warga dalam kegiatan hariannya. Pembentukan kelompok pengelola air Gua Suruh juga dikelola secara bersama, warga secara gotongroyong menanggung penggunaan listrik guna menghidupkan pompa air.

\section{HASIL KEGIATAN}

\section{Peta Gua (Luweng) dan Debit Air Sungai Bawah Tanah Gua Suruh}

Bentang lahan karst memiliki peran yang sangat penting bagi lingkungan. Bentang lahan karst menyediakan jasa ekosistem seperti air bersih, bahan-bahan material, dan menjadi agen pengendali perubahan iklim (Brinkmann dan Jo Garren, 2011 dala Adji, 2006). Di samping sumberdaya air, kawasan karst memiliki 
berbagai sumber daya yang sangat potensial untuk dikembangkan seperti sumberdaya lahan, sumberdaya hayati, dan potensi bentang lahan baik permukaan ataupun bawah permukaan (Suryatmojo, 2006). Kawasan karst memiliki fungsi ekosistem yang serupa dengan hutan rimba yaitu sebagai pengatur tata air khususnya air bawah tanah dan penyimpan potensi karbon. Kerusakan lingkungan pada bentanglahan karst seperti akibat penambangan akan mengakibatkan matinya sumber air bawah tanah yang berlimpah.

Kondisi permukaan wilayah bertopografi karst pada umumnya kering dan kritis, namun demikian, di bagian bawah permukaan terdapat potensi sumber air yang sangat berlimpah. Sumber air Sungai Bawah Tanah Gua Suruh di karst Gunungsewu di Desa Pucung, Kecamatan Eromoko, Kabupaten Wonogiri adalah contoh akan melimpahnya air sungai bawah tanah daerah karst. Potensi yang terkandung pada sumber air tersebut mencapai 8 liter/detik, sementara hingga saat ini yang termanfaatkan baru mencapai 4 liter/detik (Giribahama, 2006).

Sifat batuan karbonat ataupun dolomit yang menjadi penyusun utama bentang lahan karst adalah memiliki banyak rekahan, celah, dan rongga pada bagian permukaan. Bagian tersebut dinamakan dengan zona epikarst yang menjadi zona penangkap air yang jatuh di tempat tersebut. Celah, rekah, dan rongga tersebut akan terhubung dengan lorong-lorong konduit yang berada di zona vadose yang berada di bawah zona epikarst. Air yang ada di permukaan pada zona epikarst akan terserap ke lorong sungai bawah tanah melalui rekahan-rekahan tersebut menuju loronglorong sungai bawah tanah di zona vadose. Zona vadose merupakan bagian batuan karbonat yang tebal, dan tidak banyak memiliki rekah. Pada zona ini lorong-lorong konduit terbentuk, yang dapat dilihat dalam bentuk gua ataupun sungai bawah tanah.
Pemetaan situasi Gua Suruh ini telah dilakukan oleh Mahasiswa Pecinta Alam Fakultas Geografi UMS "Giri Bahama" secara bertahap mulai tahun 2001 hingga tahun 2009. Kegiatan awal dilakukan terkait dengan program pelatihan penelusuran gua (caving) secara periodic sebagai pengkaderan anggota Giri Bahama dalam pelestarian lingkungan hidup. Ditemukaannya air sungai awah tanah dengan debit yang relatif konstan sepanjang tahun, telah menginspirasi untuk dilakukan kegiatan pengelolaan air sungai bawah yang bertujuan untuk penyediaan kebutuhan air penduduk Desa Pucung. Gua Suruh ini memiliki lorong vertical atau sumuran sedalam $17 \mathrm{~m}$ dan 11,5 m dengan lorong sepanjang $1.500 \mathrm{~m}$ yang di dalamnya terdapat sungai bawah tanah dengan debit rata-rata 2 lt/dt. Adapun hasil pemetaan lorong Gua Suruh dan Gambaran Tiga Dimensi Gua Suruh dapat dilihat pada Gambar di Lampiran 1 dan Gambar di Lampiran 2.

Pemetaan Gua Suruh dalam kegiatan ini juga digunakan sebagai pelatihan pemuda Desa dalam kegiatan pemandu penelusuran gua. Diharapkan dengan pemahaman pemuda desa terhadap kegiatan penelusuran gua dapat dijadikan tambahan penghasilan dari jasa pemandu wisata Caving Gua Suruh. Pelatihan penelusuran gua ini juga dimaksudkan untuk pemeliharaan pompa air yang dipasang di bendungan sungai bawah tanah.

\section{Pelatihan Pengelolaan Air Sungai Bawah Tanah Gua Suruh}

Kawasan Karst adalah salah satu kawasan yang memiliki potensi penting dari sisi sosial - ekonomi dan pengetahuan. Kawasan Karst juga memiliki fungsi hidrologi - tata air yang memiliki arti penting dalam mendukung keberlangsungan kehidupan mahluk hidup di atasnya. Kawasan Karst dinyatakan sebagai kawasan lindung geologi yang merupakan salah satu 
kawasan lindung nasional karena memiliki keunikan serta kekhasan dan memiliki payung hukum Peraturan Pemerintah Nomor 26 Tahun 2008 tentang RTRWN - Rencana Tata Ruang Wilayah Nasional, pasal 60, ayat (2), huruf f. Sementara, kawasan lindung geologi adalah kawasan yang memiliki fungsi utama melindungi lingkungan geologi. Lingkungan geologi adalah segenap kulit bumi yang mempengaruhi secara langsung terhadap kondisi dan keberadaan masyarakat.

Penetapan kawasan Kars sebagai kawasan lindung juga mengacu pada Keputusan Menteri Energi dan Sumber Daya Mineral - ESDM Nomor 1456.K/20/ $\mathrm{MEM} / 2000$ tentang pedoman pengelolaan kawasan Karst yang dapat dibagi menjadi tiga kelas kawasan Karst. Pertama, kawasan Karst kelas I yang memiliki satu atau lebih kriteria, seperti memiliki fungsi sebagai penyimpan air tanah permanen, memiliki gua-gua dan sungai bawah tanah aktif, terdapat gua-gua dan speleotom aktif dan mempunyai kandungan flora dan fauna khas. Kedua, kawasan Karst kelas II yang memiliki salah satu atau semua kriteria, seperti mempunyai fungsi pengimbuh air bawah tanah, memiliki gua-gua kering dan speleotem sudah tidak aktif, tempat tinggal fauna yang memberi nilai dan manfaat ekonomi. Ketiga, kawasan Karst kelas tiga, dimana tidak memiliki kriteria kelas I maupun kelas II. Berdasarkan Kepmen ESDM itu, kawasan Karst kelas I diarahkan sebagai kawasan lindung, kawasan Karst kelas II dapat masuk kawasan lindung ataupun budi daya, setelah dilakukan penyelidikan geologi lingkungan. Sementara, kawasan Kars kelas III masuk kawasan budi daya.

Pemahaman masyarakat di Desa Pucung akan peranan Kawasan Karst sangat baik, semangat masyarakat di Desa Pucung untuk kelestarian ketersediaan air tanah Gua Suruh sangat tinggi. Setelah dilakukan pelatihan terkait pengelolaan lingkungan untuk kelestarian hijauan yang dapat meningkatkan resapan air hujan yang jatuh di wilayah tangkapan, masyarakat telah membentuk satuan pengaman lingkungan. Hasil musyawarah warga telah terbentuk Organisasi Pengelolaan Air Bersih "Tirta Gua Suruh" yang diperkuat oleh Surat Keputusan Kepala Desa Pucung Nomor 03 Tahun 2014 tentang Organisasi Pengelolaan Air Bersih Tirta Gua Suruh. Sekretaris organisasi pengelolaan air Gua Suruh ini di Dusun Kangkung.

Pada kegiatan ini juga dilakukan pendampingan kepada Pengelolaan Air Gua Suruh dalam manajemen air sebagai aset desa. Masyarakat di Desa Pucung telah sepakat dalam pembayaran/restribusi penggunaan air walaupun belum ada sistem pencatatan dengan meter air. Distribusi air Gua Suruh masih terbatas di perempatan jalan diantara rumah warga, prinsipnya pengambilan air terpusat dengan menggunakan alat ember yang masih sederhana. Perhitungan penggunaan air didasarkan pada kebutuhan rata-rata jumlah anggota keluarga tiap rumahtangganya. Kegiatan ini selain dapat memenuhi kebutuhan air juga memberi keuntungan ekonomis yang sangat tinggi kepada masyarakat Desa Pucung. Pada tahun 2014 ini harga air bersih tiap tengki kapasitas 4 $\mathrm{m}^{3}$ seharga Rp 300.000 sehingga harga air bersih adalah $\mathrm{Rp} 75.000 / \mathrm{m}^{3}$. Keberhasilan pengangkatan air gua Suruh mampu menurunkan pengeluaran untuk membeli air menjadi hanya $\mathrm{Rp} 5.000 / \mathrm{m}^{3}$ atau penghematan hingga 15 kali lipat. Adapun gambaran Organisasi Pengelolaan Air Bersih dapat dilihat pada Gambar Lampiran 2 berikut. Ketersediaan air bagi penduduk Desa Pucung yang berusia produktif sekitar 1.253 jiwa akan terlibat dalam kegiatan yang berkelanjutan dalam pemanfaatan air untuk budidaya peternakan lele atau belut serta pertanian sayuran yang dibutuhkan 
sehari-hari (cabai, terong, bayam, dan jagung).

\section{Distribusi Air Sungai Bawah Tanah Gua Suruh}

Kegiatan utama dari pengabdian masyarakat di Desa Pucung ini adalah masalah distribusi air pasca pengangkatan air sungai bawah tanah di Gua Suruh. Berdasarkan kajian topografi wilayah Desa Suruh menggunakan Citra Satelit Ekonos 2004 (Gambar Lampiran 3), selanjutnya ditentukan lokasi reservoar air untuk pendistribusian air Gua Suruh dan peta rencana distribusi air ke setiap Dusun di Desa Pucung ini. Gambaran situasi pendistribusian air Gua Suruh dapat dilihat pada Gambar di Lampiran 4.

Masyarakat yang diberdayakan dalam kegiatan pengangkatan dan distribusi air bawah tanah di Gua Suruh adalah seluruh warga yang tinggal di Dusun Brengkut 72 KK (294 jiwa). Sebagian besar warga adalah petani dan buruh dengan penghasilan di bawah rata-rata upah minimal regional (UMR) mengharap sekali masalah kebutuhan air segera dapat diatasi. Setiap musim kemarau, ketika bak air dan telaga sudah kering mengandalkan bantuan droping air yang terbatas untuk minum saja sementara mereka harus menahan tidak mandi dengan layak. Mereka membutuhkan pendamping terkait cara pengelolaan air bawah tanah di dalam Gua Suruh yang sangat besar debitnya namun belum dapat dimanfaatkan. Kegotongroyongan sebagai masyarakat pedesaan masih sangat besar dari Penduduk Dusun Brengkut, secara bergantian penduduk sanggup memberi akomodasi makan-minum sehari-hari. Kendala saluran listrik dari PLN belum mencapai dusun ini, sehingga sepakat menjalin kerjasama dengan warga Dusun Kangkung selanjutnya sumber air akan dikelola bersama untuk warga di keduadusun.

Warga Dusun Kangkung yang terdiri dari 69 KK (276 jiwa) mempunyai masalah yang sama dengan warga Dusun Brengkut dalam penyediaan air bersih untuk kebutuhan sehari-hari. Akses jalan antardesa yang melewati dusun ini paling mudah yang menjadikan akses gardu induk listrik PLN ada di Dusun ini, selanjutnya baru didistribusikan ke dusun-dusun lain di wilayah Desa Pucung. Dusun Kangkung menjadi garda depan memasuki Desa Pucung, mempunyai wilayah yang letaknya paling tinggi dibandingkan wilayah lain di Desa Pucung sehingga layak sebagai lokasi tower air untuk pendistribusian ke warga. Keberhasilan program pengangkatan air sungai bawah tanah di Gua Suruh sangat tergantung pada akses listrik PLN sebagai pembangkit pompa air yang besar yang langsung terakses dari Dusun Kangkung ini. Pemuda di Dusun Kangkung ini juga telah bersedia untuk menjadi pemandu kegiatan penelusuran Gua yang selanjutnya dapat digunakan sebagai ajang pelestarian gua.

\section{SIMPULAN DAN SARAN}

\section{Simpulan}

Kegiatan Ipteks bagi Masyarakat (IbM) ini telah berhasil dalam memberi pemahaman kepada masyarakat di Desa Pucung pentingnya pemeliharaan ekosistem kawasan karst dalam menjaga kebutuhan air bersih. Kelestarian tersedianya air di Sungai bawah tanah Gua Suruh apabila masyarakat memelihara hijauan yang dapat mengikat dan menyimpan air hujan yang jatuh di Wilayah ini. Masyarakat Desa Pucung telah membentuk Organisasi Pengelolaan Air "Tirta Gua Suruh" yang menghimpun konstribusi warga dalam pengelolaan air bersih. Distribusi air bersih masih terbatas pada titik-titik yang berada di perempatan jalan yang memungkinkan warga di satu Dusun dapat mengambilnya, sehingga belum sampai menjangkau ke masing-masing rumah.

\section{Saran}


Kelanjutan program IbM ini adalah distribusi air bersih ke setiap rumah dengan kontrol meter air. Adanya alat kontrol air akan mengurangi masalah di masa datang ketika jumlah penduduk semakin meningkat. Sifat kegotongroyongan masyarakat tetap harus terus dijaga untuk upaya kelestarian sumber air di Gua Suruh.

\section{PERSANTUNAN}

Penulis mengucapkan terimakasih yang sebesar-besarnya kepada Direktorat Jendral Pendidikan Tinggi yang telah membiayai Program pengabdian masyarakat melalui pendanaan Ipteks bagi Masyarakat (IbM) ini. Ucapan terimakasih juga disampaikan kepada Bapak Agus Ulinuha, Ph.D selaku Ketua LPPM Universitas Muhammadiyah Surakarta yang telah membantu dalam pelaksanaan pengabdian ini. Kepada Bapak Kepala Desa Pucung, warga masyarakat Pucung, dan seluruh Mahasiswa Pecinta Alam GIRBAHAMA yang telah bersama-sama saling membantu dalam pelaksanaan kegiatan ini, semoga jalinan persaudaraan kita dapat terus

berlanjut dalam kaderisasi peduli kelestarian lingkungan karst.

\section{DAFTAR PUSTAKA}

Adji, T., N., 2006., Kondisi Darah Tangkapan Sungai Bawah Tanah Karst Gunungsewu dan Kemungkinan Dampak Lingkungannya terhadap Sumberdaya Air (Hidrologis) karena Aktivitas Manusia, Seminar UGK-BP DAS SOP, Yogyakarta: Fakultas Geografi UGM.

Adji, T. N., Sudarmadji, Woro, S., Hendrayana, H., Hariadi, B., 2006. The Distribution of Flood Hydrograph Recession Constant of Bribin River for Gunungsewu Karst Aquifer Characterization. Gunungsewu-Indonesian Cave and Karst Journal, Vol. 2. No. 2.

Anonim, 2012, Peraturan Menteri Energi dan Sumberdaya Mineral Republik Indonesia Nomor 17 tahun 2012 tentang Penetapan Kawasan Bentang Alam Karst. Jakarta: Dirjen Energi dan Sumberdaya Mineral RI

Brinkman, R., Garren, S., J., 2011. Karst and Sustainability. Karst Management. DOI : 10.1007/ 978-94-007-1207-2_16.

Risyanto, Jamulya, Woro., S., Halim, Y., Sriyono, 2001. Identifikasi kerusakan Lingkungan Akibat Penambangan Bahan Galian Golongan C di Kecamatan Paciran Kabupaten Lamongan dan Kecamatan Penceng Kabupaten Gresik Propinsi Jawa Timur, Prosiding Seminar Hasil-Hasil Penelitian Fakultas Geografi UGM Tahun 2001. Yogyakarta: Fakultas Geografi UGM.

Suryatmojo, H., 2006. Strategi Pengelolaan Ekosistem Karst di Kabupaten Gunungkidul. Seminar Nasional Strategi Rehabilitasi Kawasan Konservasi di Daerah Padat Penduduk. Yogyakarta: Fakultas Kehutanan UGM. 
